\title{
O homem sereia, de Samanta Schweblin
}

Emilia Magali Spahn (UFSCar) Wilson Alves Bezerra (UFSCar)

Estou sentada no bar do porto, esperando Daniel, quando vejo o homem sereia me olhando do cais. Está em cima da primeira coluna de concreto, onde a água ainda não chega na praia, a uns cinquenta metros. Demoro para reconhecê-lo, para compreender exatamente o que ele é, tão homem da cintura para cima, tão sereia da cintura para baixo. Olha para um lado, depois tranquilamente para o outro, e finalmente volta a olhar para mim. Meu primeiro impulso é me levantar, mas sei que o Italiano, o dono do bar, é amigo do Daniel, e fica me vigiando do balcão. Disfarço procurando entre as coisas da mesa a conta do café. O Italiano se aproxima para ver se está tudo bem, insiste que o Daniel já deve estar chegando, que é melhor eu esperar. Digo para ele ficar tranquilo, que daqui a pouco eu volto. Deixo cinco pesos em cima da mesa, pego a minha bolsa e saio. Não tenho um plano para o homem sereia, simplesmente saio do bar e caminho na direção dele. Contrariamente à ideia que se tem das sereias, lindas e bronzeadas, ele não só é de outro sexo como também é bem pálido. Mas torneado, musculoso. Quando ele me vê, cruza os braços - as mãos embaixo das axilas, os polegares para cima - e sorri. Acho um gesto malandro demais para um homem sereia e me arrependo de estar caminhando até ele com tanta segurança, com tanta vontade de falar com ele, e me sinto estúpida. Mas já é tarde para voltar. Ele espera eu me aproximar e então diz:

- Oi.

Paro.

- O que faz uma morena tão sozinha, no cais? 
- Achei que talvez... - não sei o que dizer. Deixo minha bolsa cair e a seguro com as duas mãos, balançando na frente dos meus joelhos. Pensei que talvez estivesse precisando de alguma coisa, como o senhor...

- Pode me chamar de você, linda - diz e me estende a mão em um gesto que me convida a subir.

Olho para as pernas dele, ou melhor, para o seu rabo brilhante se agitando em cima do concreto. Entrego a bolsa para ele. Ele a segura junto ao corpo. Encaixo um pé no cais e seguro a mão que ele me oferece de novo. Ele tem a pele gelada, como peixe congelado. Mas o sol está alto e forte, o céu é de um azul intenso, o ar tem cheiro de limpeza e quando me acomodo ao seu lado sinto que o frescor de seu corpo me enche de uma felicidade vital. Fico embaraçada e largo a mão dele. Não sei o que fazer com as mãos. Sorrio. Ele ajeita o cabelo - tem um topete bem americano - e pergunta se eu tenho cigarro. Respondo que não fumo. A pele dele é lisa, nenhum só pelo em todo o corpo, e cheia de pequenas auréolas de polvilho branco, quase invisíveis, formadas talvez pelo sal do mar. Vê que estou olhando para ele e sacode um pouco os braços. Tem o abdômen definido, nunca vi uma barriga assim.

- Pode tocar - ele diz, acariciando o próprio abdômen -; no centro não tem um destes, né?

Aproximo uma mão, ele se adianta, agarra a minha entre a sua e seu abdômen também gelado. Me mantém assim por alguns segundos, e depois diz:

- Me conta de você - e me solta com suavidade. Como estão as coisas?

- Minha mãe está doente, os médicos acham que ela não vai aguentar muito.

Olhamos juntos para o mar.

- Que pena... - diz ele.

- Mas esse não é o problema - digo -, o que me preocupa é o Daniel. O Daniel está mal e isso só piora as coisas.

- Ele tem dificuldade para aceitar a situação da sua mãe?

Digo que sim.

- São só vocês dois de irmãos?

- Isso.

- Pelo menos podem dividir as coisas. Eu sou filho único e minha mãe é muito exigente. 
- Somos dois mas é ele quem faz tudo. Eu tenho que ficar tranquila, não posso ter emoções fortes. Tenho um problema, aqui, no coração; eu acho que é no coração. Então eu mantenho distância. Pela minha saúde...

- E onde está o Daniel agora?

- Ele não é pontual. Passa o dia todo correndo de um lado para o outro. Tem um grande problema para organizar o tempo.

- O qual é o signo dele? Peixes?

- Touro.

- Nossa! Que signo!

- Tenho bala de menta - digo. Você quer?

Diz que sim e me passa a bolsa, que ficou do lado dele.

- Passa o dia todo pensando onde vai arrumar dinheiro para pagar isto, para aquilo outro. O tempo todo querendo saber o que é que eu estou fazendo, onde é que eu vou estar, com quem...

- Ele mora com sua mãe?

- Não. Minha mãe é como eu, somos mulheres independentes e precisamos de nosso espaço. Ele acha que é perigoso eu morar sozinha. Então sem cerimônia ele me diz: "Eu acho que é perigoso uma menina como você morar sozinha". Ele quer pagar uma mulher para ficar o dia inteiro atrás de mim. Claro que eu nunca aceitei.

Dou uma bala para ele e pego outra para mim.

- Você mora aqui perto?

- Ele me alugou uma casinha a uns quarteirões daqui: ele acha que este bairro é muito mais seguro. E faz amigos por aqui, fala com os vizinhos, com o Italiano, quer saber tudo, controlar tudo, é realmente insuportável.

- Meu pai era assim.

- Pois é, só que ele não é o meu pai. Meu pai morreu, por que é que tenho que aguentar um pai-irmão se meu pai está morto?

- Bom, talvez ele só queira tentar cuidar de você.

Rio, mas com sarcasmo, na realidade, o comentário quase acaba com meu bom humor, e acho que ele consegue perceber isso.

- Não, não. Acho que o caso não é de tentar cuidar de mim, é mais complicado do que você pensa.

Ele fica me olhando. Tem uns olhos azuis claros, muito claros. 
- Me conta.

- Ah, não. Acredita em mim, não vale a pena: um dia tão bonito.

- Por favor.

Junta as palmas das mãos e implora com um gesto engraçado, como um anjo a ponto de chorar. Às vezes, quando ele fala comigo, o rabo prateado se ondula um pouco nas pontas e me roça os tornozelos. Mesmo um pouco ásperas, suas escamas não me machucam, é uma sensação agradável. Eu não digo nada, e as barbatanas vão se aproximando cada vez mais.

- Me conta...

- É que a minha mãe... Ela não está apenas doente: a verdade é que a coitada está totalmente louca...

Suspiro e olho o céu. O céu azul claro, absoluto. Depois nos olhamos. Pela primeira vez reparo em seus lábios. Serão também gelados? Pega minhas mãos, as beija e diz:

- Você acha que a gente podia sair? Você e eu, um dia destes... A gente podia sair para jantar, ou ir ao cinema, adoro cinema.

Beijo e sinto o frio de sua boca despertando cada célula do meu corpo, como uma bebida gelada em pleno verão. Não é só uma sensação, é uma experiência reveladora, porque sinto que já nada pode ser igual. Ainda não posso dizer a ele que o amo: ainda não, tem que passar mais tempo, temos que fazer as coisas passo a passo. Primeiro ele no cinema, depois eu no fundo do mar. Mas a decisão já estava tomada, é irrevogável. Eu, que toda a minha vida acreditei que se vive por um único amor, achei o meu no cais, junto ao mar, e me segura agora decidido pela mão, e me olha com seus olhos transparentes, e me diz:

- Para de sofrer, morena, ninguém mais vai te fazer mal.

Escuto uma buzina ao longe, lá da rua. Identifico em seguida: é o carro de Daniel. Olho por cima do ombro de meu homem sereia. O Daniel desce com pressa e vai direto ao bar. Não parece ter me visto.

- Já volto - digo.

Me abraça, me beija de novo. Te espero, diz, e me empresta o braço como corda para eu poder descer com maior comodidade. Logo me alcança a bolsa.

Corro até o bar. Daniel está falando com o Italiano e me vê.

- Onde você estava? Combinamos de nos encontrar na sua casa, não no bar.

Não é verdade, mas não digo nada, isso não importa agora. 
- Preciso falar contigo - digo.

- Vamos para o carro, a gente fala no carro.

Pega meu braço, com delicadeza, mais com aquela atitude paternal que tanto me irrita, e a gente sai. O carro está a uns metros, mas me detenho.

- Me solta.

Ele larga minha mão mas continua indo para o carro e abre a porta.

- Vamos, está tarde. O médico vai matar a gente.

- Não vou a lugar nenhum, Daniel.

Daniel para.

- Vou ficar aqui - digo -, com o homem sereia.

Fica me olhando um momento. Me viro em direção ao mar. Ele, belo e prateado no cais, levanta seu braço para nos cumprimentar. E ainda assim, Daniel entra no carro e abre a porta do meu lado. Então não sei o que fazer, e quando não sei o que fazer, o mundo parece um lugar terrível para alguém como eu, e então me sinto muito triste. Por isso penso: é só um homem sereia, é só um homem sereia, enquanto subo no carro e tento me acalmar. Pode ser que esteja aí outra vez amanhã, me esperando.

\section{E1 hombre sirena}

Estoy sentada en el bar del puerto, esperando a Daniel, cuando veo al hombre sirena mirarme desde el muelle. Está sobre la primera columna de hormigón, donde el agua todavía no llega a la playa, a unos cincuenta metros. Tardo en reconocerlo, en entender qué es exactamente, tan hombre de la cintura para arriba, tan sirena de la cintura para abajo. Mira hacia un lado, después tranquilamente hacia el otro, y al fin vuelve a mirar hacia acá. Mi primer impulso es pararme, pero sé que el Tano, el dueño del bar, es amigo de Daniel, y me vigila desde la barra. Disimulo buscando entre las cosas de la mesa la cuenta del café. El Tano que se acerca para ver que todo esté bien, insiste en que Daniel ya debe estar por llegar, que debo esperar. Le digo que se quede tranquilo, que enseguida vuelvo. Dejo cinco pesos sobre la mesa, tomo mi cartera y salgo. No tengo un plan para el hombre sirena, simplemente dejo el bar y camino en su dirección. Contra la idea que se tiene de las sirenas, hermosas y bronceadas, éste no solo es del otro sexo 
sino que es bastante pálido. Pero macizo, musculoso. Cuando me ve se cruza del brazo -las manos bajo las axilas, los pulgares hacia arriba-, y sonríe. Me parece un gesto demasiado canchero para un hombre sirena y me arrepiento de estar caminando hacia él con tanta seguridad, con tantas ganas de hablarle, y me siento estúpida. Él espera a que yo me acerque -ya es tarde para volver- y entonces dice:

- Hola.

Me detengo.

- ¿Qué hace una morocha tan sola, en el muelle?

- Pensé que quizá... -no sé qué decir. Dejo caer la cartera, la sostengo en ambas manos, colgando frente a mis rodillas-, pensé que quizá necesitaba algo, como usted...

- Tuteame, preciosa - dice, y me tiende la mano en un gesto que me invita a subir.

Miro sus piernas o, mejor dicho, su cola brillante que cuelga sobre el hormigón. Le paso la cartera. La toma, la deja junto a él. Trabo un pie contra el muelle y tomo la mano que vuelve a ofrecerme. Tiene la piel helada, como pescado de congelador. Pero el sol está alto y fuerte, y el cielo es de un azul intenso, y el aire huele a limpio, y para cuando me acomodo junto a él siento que la frescura de su cuerpo me llena de una felicidad vital. Me da vergüenza y me suelto. No sé qué hacer con las manos. Sonrío. Él se arregla el pelo -tiene un jopo muy a lo americano- y pregunta si traigo cigarrillos. Digo que no fumo. Tiene la piel lisa, ni un solo pelo en todo el cuerpo, y llena de pequeñas aureolas de polvillo blanco, apenas visibles, quizá formadas por la sal del mar. Ve que lo miro y se las sacude un poco de los brazos. Tiene los abdominales marcados, nunca vi una panza así.

- Podés tocarme -dice, acariciándose los abdominales-: no hay así en el centro, ¿ंo sí?

Acerco una mano, él se adelanta, la aprisiona entre la suya y sus abdominales también helados. Me tiene así algunos segundos, y después dice:

- Contame de vos -y me suelta con suavidad-. ¿Cómo va todo?

- Mamá está enferma, los médicos no creen que aguante mucho más.

Miramos juntos el mar.

- Qué mal... - dice él.

- Pero ese no es el problema -digo-, el que me preocupa es Daniel. Daniel está mal y eso no ayuda.

- ¿Le cuesta asumir lo de su madre? 
Asiento.

- ¿Son dos hermanos?

- Sí.

- Al menos pueden dividirse las cosas. Yo soy hijo único y mi madre es muy absorbente.

- Somos dos pero lo hace todo él. Yo necesito estar descansada, no puedo permitirme emociones fuertes. Tengo un problema, acá, en el corazón, yo creo que es del corazón. Así que mantengo distancia. Por mi salud...

- ¿Y dónde está Daniel ahora?

- Es impuntual. Está todo el día corriendo de acá para allá. Tiene un gran problema con la organización de sus tiempos.

- ¿De qué signo es? ¿Piscis?

- Tauro.

- ¡Uff! Qué signo.

- Tengo pastillas de menta -digo-, ¿querés?

Dice que sí y me pasa la cartera, que quedó de su lado.

- Está todo el día pensando de dónde va a sacar dinero para pagar esto, de dónde para lo otro. Todo el tiempo queriendo saber qué estoy haciendo, dónde voy a estar, con quién...

- ¿Vive con tu madre?

- No. Mamá es como yo, somos mujeres independientes y necesitamos nuestro espacio. Él considera que es peligroso que yo viva sola. Así nomás me lo dice: "Yo creo que es peligroso que una chica como vos viva sola". Quiero pagarle a una mujer para que esté todo el día detrás mío. Por supuesto que nunca acepté.

Le paso una pastilla y tomo otra para mí.

- ¿Vivís por acá?

- Me alquila una casita a unas cuadras: cree que este barrio es mucho más seguro. Y se hace amigos por acá, habla con los vecinos, con el Tano, quiere saber todo, controlar todo, es realmente insoportable.

- Mi padre era así.

- Sí, pero él no es papá. Papá está muerto, ¿por qué tengo que soportar un papá-hermano si papá está muerto?

- Bueno, quizás sólo intenta cuidarte. 
Me río sarcásticamente, en realidad, el comentario casi arruina mi humor, y creo que él alcanza a darse cuenta.

- No, no. No se trata de cuidarme, es más complicado de lo que pensás.

Se queda mirándome. Tiene ojos celestes, muy claros.

- Contame.

- Ah, no. Creeme, no vale la pena: es un día hermoso.

- Por favor.

Une las palmas de las manos, y me ruega con una mueca graciosa, como un ángel a punto de llorar. A veces, cuando me habla, la aleta plateada se ondula un poco en las puntas y me roza los tobillos. Aunque son ásperas, las escamas no me lastiman, es una sensación agradable. Yo no le digo nada, y las aletas se acercan cada vez más.

- Contame...

- Es que mamá... Ella no solo está enferma: la verdad es que la pobre está totalmente loca...

Suspiro y miro el cielo. El cielo celeste, absoluto. Después nos miramos. Por primera vez reparo en sus labios. ¿Serán también helados? Me toma de las manos, las besa y dice:

- ¿Crees que podríamos salir? Vos y yo, un día de estos... Podríamos ir a cenar, o al cine, me encanta el cine.

Le doy un beso y siento el frío de su boca despertar cada célula de mi cuerpo, como una bebida helada en pleno verano. No es solo una sensación, es una experiencia reveladora, porque siento que ya nada puede ser igual. Aunque no puedo decirle que lo amo: no todavía, debe pasar más tiempo, debemos hacer las cosas paso a paso. Primero él al cine, después yo al fondo del mar. Pero la decisión está tomada, es irrevocable. Yo, que toda la vida creí que se vive de un único amor, encontré al mío en el muelle, junto al mar, y me toma ahora francamente la mano, y me mira con sus ojos transparentes, y me dice:

- No sufras más, morocha, ya nadie puede hacerte daño.

Una bocina suena a lo lejos, desde la calle. La identifico enseguida: es el auto de Daniel. Miro por sobre el hombro de mi hombre sirena. Daniel baja apurado y va directo hacia el bar. No parece haberme visto.

- Ahora vuelvo - digo.

Me abraza, vuelve a besarme; "Te espero", dice, me presta su brazo como una soga para que pueda bajar más cómoda y me alcanza la cartera. 
Corro hasta el bar. Daniel está hablando con el Tano y me ve.

- ¿Dónde estabas? Quedamos en tu casa, no en el bar.

No es cierto, pero no le digo nada, eso no importa ahora.

- Necesito hablarte - digo.

- Vamos al auto, hablamos en el auto.

Me toma del brazo, con delicadeza, pero con esa actitud paternal que tanto me enerva, y salimos. El auto está a unos metros, pero me detengo.

- Soltame.

Me suelta pero sigue hacia el auto y abre la puerta.

- Vamos, es tarde. El médico va a matarnos.

- No voy a ningún lado, Daniel.

Daniel se detiene.

- Voy a quedarme acá -digo-, con el hombre sirena.

Se queda mirándome un momento. Me doy vuelta hacia el mar. Él hermoso y plateado sobre el muelle, levanta su brazo para saludarnos. Y aun así, Daniel entra al auto y abre la puerta de mi lado. Entonces no sé qué hacer, y cuando no sé qué hacer, el mundo me parece un lugar terrible para alguien como yo, y me siento muy triste. Por eso pienso: es solo un hombre sirena, es solo un hombre sirena, mientras subo al auto y trato de tranquilizarme. Puede estar ahí otra vez mañana, esperándome.

\section{Nota dos tradutores}

A escritora argentina Samanta Schweblin (Buenos Aires, 1978) é autora dos livros de contos El núcleo del distúrbio (Planeta, 2002), Pájaros en la boca (Literatura Random House, 2009) e Siete casas vacías (Páginas de Espuma, 2015), e do romance Distancia de rescate (Literatura Random House, 2014). Sua obra obteve numerosos prêmios e foi traduzida, parcialmente, para mais de vinte línguas. Em português, especificamente, circula o seu romance Distância de resgate, publicado pela editora Record em 2016, e uma coletânea, publicada pela editora Saraiva em 2012, que reúne contos de seus dois primeiros livros, ainda que leve por nome o título do segundo, Pássaros na boca. Na versão brasileira, não consta o conto aqui traduzido.

As histórias que Schweblin apresenta interrogam a vida cotidiana, ao suscitar eventos insólitos e narrar comportamentos que fraturam os contratos sociais. Seus textos, às vezes com traços mais fantásticos, às vezes com traços mais realistas, 
são um convite a questionar as certezas e problematizar o nosso olhar. Trata-se de narrativas inquietantes, marcadas pelo medo, a loucura e a incompreensão, que postulam a existência de múltiplos pontos de vista e que exploram a diversidade e a proliferação de sentidos.

\section{Referência bibliográfica}

SCHWEBLIN, Samanta. El hombre sirena. In: . Pájaros en la boca. $4^{\mathrm{a}}$ ed. Buenos Aires:

Literatura Random House, 2016. 